\title{
Inoculated Seed Endophytes Modify the Poplar Responses to Trace Elements in Polluted Soil
}

\author{
Francesca Vannucchi ${ }^{1}$, Valeria Imperato ${ }^{2}$, Anabel Saran ${ }^{2,3}{ }^{\mathbb{D}}$, Svetoslav Staykov ${ }^{2}$, Jan D’Haen ${ }^{4,5}$ (D), \\ Luca Sebastiani ${ }^{1}$, Jaco Vangronsveld ${ }^{2,6}$ (D) and Sofie Thijs ${ }^{2, *(\mathbb{D})}$
}

\section{check for} updates

Citation: Vannucchi, F.; Imperato, V.; Saran, A.; Staykov, S.; D’Haen, J.; Sebastiani, L.; Vangronsveld, J.; Thijs, S. Inoculated Seed Endophytes Modify the Poplar Responses to Trace Elements in Polluted Soil. Agronomy 2021, 11, 1987. https://doi.org/ 10.3390/agronomy11101987

Academic Editors: Maria Pilar Bernal, Paula Alvarenga and Katarzyna Turnau

Received: 30 August 2021

Accepted: 28 September 2021

Published: 30 September 2021

Publisher's Note: MDPI stays neutral with regard to jurisdictional claims in published maps and institutional affiliations.

Copyright: (c) 2021 by the authors. Licensee MDPI, Basel, Switzerland. This article is an open access article distributed under the terms and conditions of the Creative Commons Attribution (CC BY) license (https:/ / creativecommons.org/licenses/by/ $4.0 /)$
1 Institute of Life Science, Scuola Superiore Sant'Anna, Piazza Martiri della Libertà 33, 56127 Pisa, Italy; francesca.vn85@gmail.com (F.V.); luca.sebastiani@santannapisa.it (L.S.)

2 Environmental Biology, Centre for Environmental Sciences, Hasselt University, 3590 Diepenbeek, Belgium; vale.imperato@gmail.com (V.I.); saran.anabel@gmail.com (A.S.); svetoslav.staykov95@gmail.com (S.S.); jaco.vangronsveld@uhasselt.be (J.V.)

3 Experimental Agropecuary Estation INTA Anguil-CONICET, Santa Rosa 6300, La Pampa, Argentina

4 Institute for Material Research (IMO), Hasselt University, Wetenschapspark 1, 3590 Diepenbeek, Belgium; jan.dhaen@uhasselt.be

5 Division IMOMEC, IMEC, Wetenschapspark 1, 3590 Diepenbeek, Belgium

6 Department of Plant Physiology and Biophysics, Institute of Biological Sciences, Faculty of Biology and Biotechnology, Maria Curie-Skłodowska University, 20-033 Lublin, Poland

* Correspondence: sofie.thijs@uhasselt.be

Abstract: Seed endophyte inoculation can enhance the plant tolerance to pollutants, which allows plant cultivation on trace element (TE) polluted soils. Methylobacterium sp. CP3 and Kineococcus endophyticus CP19 were tested in vitro for their tolerance to $\mathrm{Zn}$ and $\mathrm{Cd}$ and their plant growth promotion traits. The in vivo effects of bioaugmentation with individual strains or both strains were tested using two poplar cultivars, Populus deltoides $x$ (P. trichocarpa $x$ P. maximowiczii) 'Dender' and 'Marke', grown in TE polluted soil for six weeks. Methylobacterium sp. was found to grow on media enriched with 0.4 and $0.8 \mathrm{mM} \mathrm{Cd}$, and both endophytes tolerated 0.6 and $1 \mathrm{mM} \mathrm{Zn}$, due to the presence of genes involved in $\mathrm{Zn}$ and Cd tolerance and transport. Methylobacterium sp. showed an extracellular ion sequestration mechanism. Production of indole-3-acetic acid by Methylobacterium sp. and K. endophyticus, as well as phosphorus solubilization by Methylobacterium sp. were observed. Bioaugmentation with both endophytes increased the shoot length of Populus 'Marke' and enhanced the $\mathrm{Mg}$ uptake in both cultivars. Inoculation with Methylobacterium sp. reduced the bioaccumulation of $\mathrm{Zn}$ in 'Marke', conferring it an excluder strategy. Methylobacterium sp. and K. endophyticus seemed to improve the plant nutritional status, which can alleviate abiotic stress.

Keywords: cadmium; Kineococcus endophyticus CP19; Methylobacterium sp. CP3; plant growth promotion; Populus; zinc

\section{Introduction}

Soil pollution by trace elements (TE) is a worldwide problem due to the negative consequences to soil quality, food safety, and human health. The main sources of TE pollution, include mining, industrial waste, phosphate fertilizers, pesticides as well as atmospheric deposition by industrial activities [1]. Globally, around 10 million sites are considered polluted, of which more than $50 \%$ by TE [2]. In the EU, about $6.2 \%$ of agricultural land is potentially polluted by TE [3], including an area of $280 \mathrm{~km}^{2}$ in the northeast of Belgium [4]. In this agricultural region, the activities of several pyrometallurgical smelters resulted in soil pollution by $\mathrm{Zn}, \mathrm{Cd}$ and $\mathrm{Pb}[4,5]$. The cultivation of TE-tolerant non-food crops in this area would allow to lower the negative impacts of the polluted soil on the environment as well as to support the local economy [6-9]. Suitable candidates belong to the Salicaceae family, which includes some woody species (i.e., poplars and willows), with high biomass production and the capability for TE phytoextraction [9-13]. In particular, 
Populus 'Dender' and 'Marke, which select cultivars of controlled crossings (P. deltoides $x$ (P. trichocarpa $x$ P. maximowiczii)), show fast growth and they are suitable for short rotation biomass production [14]. The cultivation of TE tolerant and fast-growing trees can allow the valorization of polluted agricultural land, through the production of biomass as for energy or other purpose as well as a gradual soil depollution by extracting TE $[15,16]$.

Trace element-tolerant microorganisms can improve plant establishment and growth under conditions of TE phytotoxicity, and thus improve the overall phytostabilization performance. Amongst these plant-associated microorganisms, endophytes interact very intimately with their host. In this mutual symbiosis, plants provide nutrients to the microorganisms, and the latter can enhance plant growth and health [17]. Specifically, endophytic bacteria can improve plant growth through the production of plant growth regulators, nitrogen fixation and by increasing the availability of some elements such as phosphorous and iron. In addition, some endophytes may possess ion sequestration capacities, reducing their phytotoxicity $[18,19]$. Sequestration mechanisms include the bioaccumulation of ions inside the cell, as well as the physical adsorption to the cell wall, binding ions to anionic functional groups and to polysaccharides on cell surfaces [20]. Seed endophytes can provide benefits to their host plants through the growth promotion and increasing their tolerance to abiotic stresses, as TE presence in soil. The core seed microbiome in wheat includes endophytes able to produce auxins and siderophores, as well as to solubilize phosphate [21]. Similar traits have been observed in cucurbit seed endophytes, resulting in increased nutrient uptake and plant growth [22]. Nicotiana tabacum possesses seed endophytes with the capability to enhance biomass production, as well as to increase $\mathrm{Cd}$ concentrations in inoculated tobacco plants under Cd stress [17]. Moreover, the transmission of such endophytes through several seed generations supports the adaptation process of plants to polluted conditions [23-26]. The exploitation of seed endophytes that occur in metallophytes can be a strategy to improve the plant tolerance to TE polluted soils [27]. Crotalaria pumila is an herbaceous plant colonizing metalliferous soils in Mexico, with a phytoextraction potential for $\mathrm{Zn}$. The bacterial seed endophytic communities of $C$. pumila have been described, including Kineococcus endophyticus CP19 and Methylobacterium sp. CP3 strains, over three seed generations. Methylobacterium is the most abundant genus of the C. pumila core microbiome, with the potential to improve the nutrient uptake and TE tolerance of the host plant. Moreover, as observed in Arabidopsis thaliana, plant colonization by Methylobacterium involves a migration towards aerial tissues through xylem vessels [28-30].

To the best of our knowledge, little information is available regarding the role and fate of inoculated endophytic bacteria in trees, like poplar, growing on TE polluted soil. For the purpose of improving our knowledge, Methylobacterium sp. CP3 and Kineococcus endophyticus CP19 strains were further characterized with regard to their TE tolerance and capability to support plant growth. Subsequently, an inoculation experiment was performed to assess the effects of inoculation of these selected endophytes on poplar TE-tolerance and uptake using Populus 'Dender' and 'Marke' cultivars, growing in soil originating from a TE polluted area (Lommel, Belgium). Additionally, we also investigated the fate of the inoculated strains, separately and in association, in plant organs, in order to elucidate whether the observed effects are due to an indirect or direct effects of the bacteria colonizing the plant.

\section{Materials and Methods}

2.1. Bacterial Strains Characterization

2.1.1. In Vitro Plant Growth Promotion Traits and TE Tolerance

Methylobacterium sp. CP3 and Kineococcus endophyticus CP19 were characterized in vitro for their potential plant growth promotion traits, production of indole-3-acetic acid (IAA) and phytate mineralization, as well as their TE tolerance and production of siderophores and organic acids. Before testing, bacterial strains were grown overnight in 
869 medium [31], and the different assays were performed after washing the bacterial cells with $10 \mathrm{mM}$ MgSO4.

IAA production was assessed according to Patten and Glick method [32]. $25 \mu \mathrm{L}$ of bacterial suspension was incubated for 4 days at $30{ }^{\circ} \mathrm{C}$ in $1 \mathrm{~mL} 1 / 10$ strength 869 medium supplemented with $0.5 \mathrm{~g} \mathrm{l}^{-1}$ tryptophan. $1 \mathrm{ml}$ of Salkowski reagent $\left(0.5 \mathrm{M} \mathrm{FeCl}_{3}\right.$ and $35 \%$ $\mathrm{HClO}_{4}$ ) was added to $0.5 \mathrm{ml}$ of supernatant and colorimetrically evaluated. Phytate mineralisation by the bacteria was estimated by measuring the halo-zones produced around colonies, growing on National Botanical Research Institute's phosphate solid medium at $28{ }^{\circ} \mathrm{C}$ for 12 days [33]. Siderophore production was verified according to the colorimetrical method proposed by Schwyn and Neilands [34]. An amount of $20 \mu \mathrm{L}$ of bacterial suspension was incubated in $800 \mu \mathrm{L}$ selective 284 medium [35], containing carbon sources and supplemented with $0,0.25$ or $3 \mu \mathrm{M}$ Fe(III)citrate (deficient, optimal and oversupplying Fe conditions, respectively) at $30^{\circ} \mathrm{C}$. After 5 days, $100 \mu \mathrm{L}$ of the blue chrome-azurol $\mathrm{S}$ (CAS) reagent was added and change of color was evaluated. Organic acid production was evaluated using the method proposed by Cunningham and Kuiack [36]. An amount of $800 \mu \mathrm{L}$ sucrose tryptone medium was added to $20 \mu \mathrm{L}$ of bacterial suspension. After a $30{ }^{\circ} \mathrm{C}$ incubation, for 5 days, $100 \mu \mathrm{L}$ of $0.1 \%(v / v)$ Alizarine red $\mathrm{S}$ was added and the production was qualitatively evaluated. The TEs with values above the threshold for Flanders legislation were selected for bacterial tolerance. The maximum inhibitory concentrations for selected bacteria were also assessed: A total of $20 \mu \mathrm{L}$ of bacterial suspension was plated on selective 284 medium supplemented with a carbon source [35], and 0.0, 0.4 and $0.8 \mathrm{mM}$ $\mathrm{CdSO}_{4}$ or $0,0.6$ and $1.0 \mathrm{mM} \mathrm{ZnSO}_{4}$. After 14 days incubation at $30{ }^{\circ} \mathrm{C}$, bacterial growth was assessed.

\subsubsection{Scanning Electron Microscopy (SEM) and EDX Analysis}

Based on TE tolerance results, Methylobacterium sp. CP3 and Kineococcus endophyticus CP19 were chosen for scanning electron microscopy (SEM) and EDX analysis. Methylobacterium sp. CP3 was grown in liquid 284 medium supplemented with $1 \mathrm{mM} \mathrm{ZnSO}_{4}$ and $0.8 \mathrm{mM} \mathrm{Cd} \mathrm{CdSO}_{4}$, Kineococcus endophyticus $\mathrm{CP} 19$ in $1 \mathrm{mM} \mathrm{ZnSO} 4$ supplemented medium. Cell fixation was performed according to the method of Holmes et al. [37]. Briefly, bacteria pellets were washed 3 times with $0.01 \mathrm{M}$ phosphate-buffered saline buffer (PBS, pH 7.0) to remove unbound ions, sugars and proteins. Pellets were resuspended in $2 \%$ glutaraldehyde for $1 \mathrm{~h}$ at room temperature. Subsequently, samples were centrifuged for $3 \mathrm{~min}$ at $3000 \times g$ and pellets were washed 3 times with Millipore water. A total of $1 \mu \mathrm{L}$ of each sample was placed on a sample holder, covered with carbon conductive tape. Then, samples were coated with a gold layer and analyzed using a Scanning Electron Microscope (FEI Quanta 200F FEG-SEM with ThermoFisher Pathfinder Alpine EDS system with UltraDry Premium (60 $\mathrm{mm}^{2}$ active area) EDS detector). Images were taken using accelerating voltages of 7.5, $12.5 \mathrm{kV}$ or $15 \mathrm{kV}$.

\subsubsection{Genome Sequencing and Assembly}

Total DNA extraction and sequencing of Methylobacterium sp. CP3 and Kineococcus endophyticus CP19 were carried out in a previously study [26]. The RAST annotation system was used to perform the open reading frame prediction and gene annotation [38]. The prokaryotic genome automatic annotation pipeline of the National Center for Biotechnology Information [39], and the platform MicroScope were performed using the tool Magnifying Genomes, MaGe (http:/ / www.genoscope.cns.fr, access date: 3 February 2021) [40]. Clusters of Orthologous Genes [41] and metabolic pathway reconstruction was carried out using the databases of Kyoto Encyclopedia of Genes and Genomes (KEGG) [42] and MetaCyc [43]. 


\subsection{Inoculation Experiment}

\subsubsection{Soil and Plant Collection}

Polluted soil was sampled in Lommel (Belgium, $51^{\circ} 12^{\prime} 41^{\prime \prime} \mathrm{N} ; 5^{\circ} 14^{\prime} 32^{\prime \prime} \mathrm{E}$ ), in an abandoned agricultural area at $500 \mathrm{~m}$ north-east of a $\mathrm{Zn}$ smelter. The soil has a sandy texture with a $\mathrm{pH}$ of 4.6-5 [9,44]. Cuttings of two poplar cultivars ('Dender' and 'Marke') were provided by Sylva nurseries (Lievegem, Belgium).

\subsubsection{Plant Inoculation}

The inoculation experiment was carried out in March and April 2019. Cuttings of the Populus cultivars 'Dender' 'Marke' were placed in water to allow root development, under greenhouse conditions $\left(25^{\circ} \mathrm{C}\right.$ day $/ 19^{\circ} \mathrm{C}$ night; $60 \%$ humidity; $500 \mathrm{~mL}$ per day nebulised watering; $400 \mu \mathrm{moL} \mathrm{cm}{ }^{-2} \mathrm{~s}^{-1}$ PAR). After the cuttings developed roots, bacterial inoculations were performed. Methylobacterium sp. CP3 and Kineococcus endophyticus CP19 were incubated at $30^{\circ} \mathrm{C}$ in 869 liquid medium for 2 days, until mid-exponential phase and an optical density of $1 \mathrm{U}$ at $600 \mathrm{~nm}\left(\approx 10^{8} \mathrm{CFU} / \mathrm{mL}\right)$ was achieved (visible spectrophotometer Novaspec Plus, Holland). The bacterial cultures were centrifuged (15 min at $4000 \mathrm{rpm}$ ) and bacterial pellets were washed 3 times with $10 \mathrm{mM} \mathrm{MgSO}_{4}$ solution. Afterwards, the pellets were resuspended in $100 \mathrm{~mL}$ of tap water and added to the cuttings in water. Cuttings of each cultivar were placed in a total of four $10 \mathrm{~L}$ containers (one container per inoculation condition). Conditions were the following: Non-inoculated (Control), Methylobacterium sp. CP3 inoculation (M), Kineococcus endophyticus CP19 inoculation (K), and Methylobacterium sp. $\mathrm{CP} 3+$ Kineococcus endophyticus $\mathrm{CP} 19$ inoculation $(\mathrm{M}+\mathrm{K})$ (Figure 1). Seven days after the inoculation, 17 cuttings of each cultivar were transferred to plastic pots, filled with $3.5 \mathrm{~kg}$ of polluted soil and kept in greenhouse conditions. Cuttings were grown on polluted soil for 6 weeks to avoid possible plant stress to improve growing conditions.
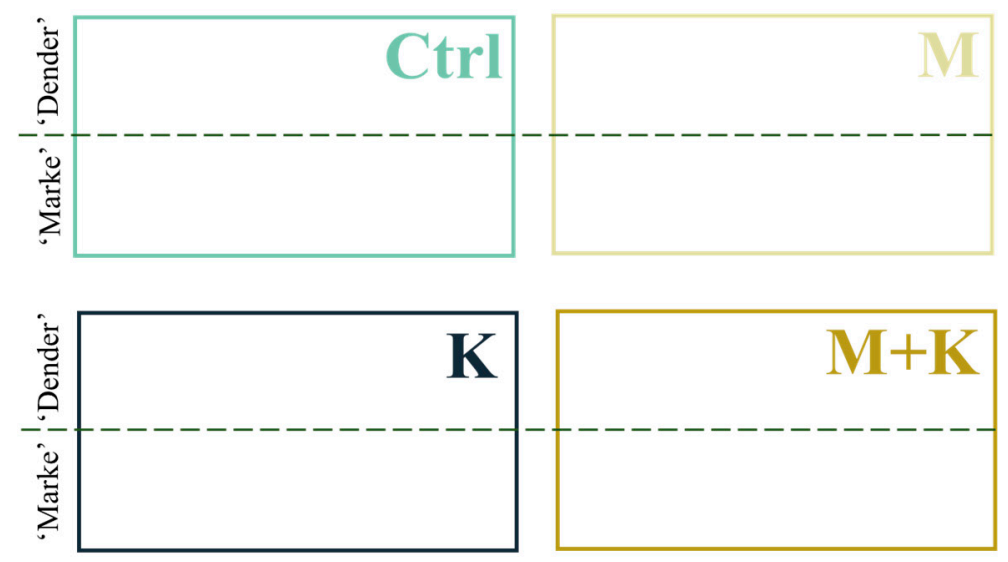

Figure 1. Scheme of inoculation setup using four $10 \mathrm{~L}$ containers, filled with tap water, in which the poplar cuttings were inoculated. Ctrl (Control): Non-inoculated cuttings; M: Methylbacterium sp. CP3 inoculation; K: Kineococcus endophyticus CP19 inoculation; M+K: Methylbacterium sp. CP3 and Kineococcus endophyticus CP19 inoculation.

\subsection{Specific Automated Ribosomal Intergenic Spacer Analyses (ARISA)}

After 6 weeks of growth, total DNA was extracted from the roots and leaf samples of 3 inoculated cuttings per condition, and from Methylobacterium sp. CP3 and Kineococcus endophyticus CP19 pure colonies, using for all the samples the E.Z.N.A. Bacterial DNA kit (Omega Bio-Tek, VWR, Leuven, Belgium). Plant samples were surface sterilized before DNA extraction with $5 \% \mathrm{NaOCl}$ for $3 \mathrm{~min}$, ethanol $70 \%$ for $3 \mathrm{~min}$ and rinsed three times with sterile water. Surface sterilization was checked by plating $1 \mathrm{~mL}$ of the rinsing water on Petri dishes filled with 869 medium. In circumstances where no colonies were observed after an incubation time of two weeks, sterilization was considered to be adequate. The 16S-23S internal transcribed spacer (ITS) regions were amplified by PCR with ITSF (5- 
GTCGTAACAAGGTAGCCGTA-3) and ITSreub (5-GCCAAGGCATCCACC-3) primers [45], using the FastStart High Fidelity PCR system, dNTPack (Sigma-Aldrich, St. Louis, USA). Afterwards, $1 \mu \mathrm{L}$ of DNA samples were loaded on a DNA-chip (DNA $1000 \mathrm{kit}$, Agilent Technologies, Diegem, Belgium) and analyzed on a 2100 Bioanalyzer (Agilent Technologies, Diegem, Belgium). Expert Software (Agilent Technologies) was used to digitalize the ARISA fingerprints, resulting in electropherograms in ASCII formats. ASCII formats were processed using the StatFingerprints package [46].

\subsection{Plant Health and Growth}

Poplar growth was examined once per week, in terms of shoot height, leaf number and area of the first three fully expanded leaves. The chlorophyll content was also estimated using a CCM-200 plus Chlorophyll Content Meter (OPTI-SCIENCES, Inc., Hudson, USA). In addition, the efficiency of photosystem II (PSII) was evaluated by the detection of chlorophyll $a$ fluorescence, using the Plant stress kit (ADC Bioscientific Ltd, Hoddesdon, UK). More specifically, the maximum quantum efficiency of PSII was measured as $F_{v} / F_{m}$, where $F_{v}$ is the variable fluorescence, calculated as the difference between maximum fluorescence $\left(\mathrm{F}_{\mathrm{m}}\right)$ and the minimum fluorescence yield $\left(\mathrm{F}_{0}\right)$. Fm was measured after application of a saturating light pulse $\left[6000 \mu \mathrm{moL}\right.$ (photon) $\left.\mathrm{m}^{-2} \mathrm{~s}^{-1}\right]$. After 6 weeks of growth, shoots and roots were harvested for determining fresh (FW) and dry weight (DW). Shoots and roots were dried in an oven at $60^{\circ} \mathrm{C}$ until unchanged weight and DW biomass were measured.

\subsection{Trace Element and Nutrient Concentrations in Soil}

Trace element and nutrient concentrations were evaluated in the soil used prior to the greenhouse experiment. Oven-dried soil samples were analyzed for total $\mathrm{Zn}$ and $\mathrm{Cd}$ concentrations and nutrients ( $\mathrm{Ca}, \mathrm{Mg}, \mathrm{Mn}, \mathrm{K}, \mathrm{Cu})$, using the USEPA $3051 \mathrm{HNO} 3$-microwave assisted digestion method [47]. Amounts of $37 \% \mathrm{HNO}_{3}$ and $37 \% \mathrm{HCl}$ solution (1:3 v:v) were added to $0.5 \mathrm{~g}$ of soil, and soil samples were digested in a microwave over (Milestone 1200 MEGA, Milestone Systems, Belgium) at $160^{\circ} \mathrm{C}$ ( $25 \mathrm{~min}$ ramp time, $10 \mathrm{~min}$ ventilation). The obtained extracts were diluted to a final volume of $50 \mathrm{~mL}$ with Millipore water and subsequently analyzed with inductively coupled plasma optical emission spectrometry (ICP-OES, Agilent Technologies, 700 series, Belgium). Plant available metal fractions were estimated by determining the exchangeable metal concentrations, while $20 \mathrm{ml} 0.01 \mathrm{M} \mathrm{CaCl}_{2}$ was added to $2 \mathrm{mg}$ of dry soil sample, and after a $4 \mathrm{~h}$ incubation at $25^{\circ} \mathrm{C}$, soil samples were centrifuged $(15,000 \times g ; 15 \mathrm{~min})$ and extracts were filtered. Cd and $\mathrm{Zn}$ concentrations in the extracts were measured using ICP-OES. All samples were analyzed in triplicate. For the quality control, blank and standard references were included in the analysis (sewage sludge amended soil, Standard Reference Material 143R, Commission of the European Communities).

\subsection{Element Concentrations in Plant Tissues}

To determine total $\mathrm{Cd}$, $\mathrm{Zn}$, micro- $(\mathrm{Cu}, \mathrm{Mn})$ and macronutrient $(\mathrm{Ca}, \mathrm{Mg}, \mathrm{K})$ concentrations in plant biomass, $0.2 \mathrm{~g}$ of dried plant roots and leaves were powdered and digested in glass tubes in a heating block, using the USEPA 3050B Acid Digestion of Sediments, Sludges, and Soils [48]. Three digestion cycles were carried out for each sample. The first one in $1 \mathrm{ml} \mathrm{HNO} 3$ (70\%) followed by one cycle in $1 \mathrm{ml} \mathrm{HCl}(37 \%)$ at $120^{\circ} \mathrm{C}$ for $4 \mathrm{~h}$. After the digestion, samples were dissolved in $\mathrm{HCl}(37 \%)$ and diluted to a final volume of $5 \mathrm{ml}(2 \% \mathrm{HCl})$ with Millipore water. The extracts were analyzed using the same ICP-OES, as mentioned before. All samples were analyzed in triplicate. Blanks (only $\mathrm{HNO}_{3}$ ) and standard references (NIST Spinach 1570a) were included.

\subsection{Bioaccumulation and Translocation Factors}

To evaluate the phytoextraction capabilities of inoculated and non-inoculated Populus 'Dender' and 'Marke' cultivars, the bioaccumulation (BAF) and translocation (Tf) factors 
were calculated after 6 weeks in polluted soil. The BAF was calculated as the ratio of total $\mathrm{Cd}$ and $\mathrm{Zn}$ concentrations in each plant organ to total the $\mathrm{Cd}$ and $\mathrm{Zn}$ concentrations detected in soil, while $\mathrm{Tf}$ as ratio of total $\mathrm{Cd}$ and $\mathrm{Zn}$ concentrations in leaves to root ones [49].

\subsection{Statistical Analysis}

After confirmation of normality (Shapiro-Wilk normality test) and homoscedasticity (Bartlett test) of the data, one-way ANOVA, followed by Tukey's Multiple Comparison Test $(p \leq 0.05)$, was applied to plant growth and photosynthetic parameters, as well as to TE concentration data in plant tissues and relative indices (bioaccumulation and translocation factors). Statistical analyses were performed using R 3.6.0. Principal Component Analysis (PCA) was computed with the main results of the experiment, in order to investigate the correlations between variables (shoot height, biomass, element concentrations, Tf and BAF) within Methylobacterium sp. CP3 and Kineococcus endophyticus CP19 inoculations. PCA that explained more than a single parameter alone (eigenvalues $>1$ ) were considered, using Orange: Data Mining Toolbox in Python.

\section{Results}

\subsection{Characterization of the Bacterial Strains}

The in vitro TE tolerance and plant growth promotion traits of Methylobacterium sp. CP3 and Kineococcus endophyticus CP19 are presented in Table 1. Methylobacterium sp. CP3 could grow in media supplemented with 0.6 and $1 \mathrm{mM} \mathrm{Zn}$, as well with 0.4 and $0.8 \mathrm{mM} \mathrm{Cd}$, while K. endophyticus CP19 only developed in Zn enriched medium (0.6 and $1 \mathrm{mM} \mathrm{Zn}$ ). Both bacterial strains produced IAA and only Methylobacterium sp. CP3 showed the capacity to solubilize phosphate.

Table 1. Trace element tolerance and in vitro plant growth promotion (PGP) traits of Kineococcus endophyticus CP3 and Methylobacterium sp. CP19. + = positive response; $-=$ negative response.

\begin{tabular}{|c|c|c|c|c|c|c|c|c|}
\hline \multirow[b]{2}{*}{ Bacteria Strains } & \multicolumn{4}{|c|}{ Metal Tolerance } & \multicolumn{4}{|c|}{ PGP Traits } \\
\hline & $\begin{array}{c}\mathrm{Cd} \\
(0.4 \mathrm{mM})\end{array}$ & $\begin{array}{c}\mathrm{Cd} \\
(0.8 \mathrm{mM})\end{array}$ & $\begin{array}{c}\mathrm{Zn} \\
(0.6 \mathrm{mM})\end{array}$ & $\begin{array}{c}\mathrm{Zn} \\
(1 \mathrm{mM})\end{array}$ & IAA & Sid & Org acid & P-mi \\
\hline K. endophyticus CP19 & - & - & + & + & + & - & - & - \\
\hline Methylobacterium sp. CP3 & + & + & + & + & + & - & - & + \\
\hline
\end{tabular}

IAA = auxine production; Sid = siderophore production; Org acid = organic acid production; P-mi = phytate mineralization.

A functional characterization of Methylobacterium sp. CP3 and Kineococcus endophyticus $\mathrm{CP} 19$ and their interaction with $\mathrm{Cd}$ and $\mathrm{Zn}$ was performed (Table 2). The draft genomes of Methylobacterium sp. CP3 and Kineococcus endophyticus CP19 disclosed the presence of genes involved in $\mathrm{Zn}$ and $\mathrm{Cd}$ transport and tolerance, especially genes of the operons czc and znu involved in the tolerance to $\mathrm{Cd}$ and $\mathrm{Zn}$. In addition, gene annotation revealed the presence in Kineococcus endophyticus CP19 of the iaaH gene which is encoding for indole-3-acetamide hydrolase in the pathway of IAA production. The draft genome of Methylobacterium sp. CP3 included the phoA gene, which is encoding for alkaline phosphatase that is involved in the mineralization of phosphate. Moreover, the absence of genes for the production of some organic acids was confirmed by the genome annotation.

SEM-EDX analysis enabled the physical interaction between bacterial strains and trace elements to be observed. Cadmium (Figure S1) and Zn (Figure S2) are clearly present on/in the bacterial cell. After 2 days of growth in liquid cultures, enriched with $0.8 \mathrm{mM}$ $\mathrm{Cd}$ (Figure S1) and $1 \mathrm{mM} \mathrm{Zn} \mathrm{(Figure} \mathrm{S2),} \mathrm{it} \mathrm{was} \mathrm{possible} \mathrm{to} \mathrm{distinguish} \mathrm{trace} \mathrm{element} \mathrm{rich}$ zones as being the brighter regions on the cell wall of Methylobacterium sp. CP3. 
Table 2. Main genes and relative encoded protein involved in Kineococcus endophyticus CP19 and Methylobacterium sp. CP3 responses to $\mathrm{Cd}$ and $\mathrm{Zn}$. ABC = ATP-binding cassette.

\begin{tabular}{|c|c|c|c|}
\hline Trace Element & Gene & Encoded Protein/Enzyme & Bacteria \\
\hline $\mathrm{Cd}, \mathrm{Zn}$ & $c z c D$ & CzcD, cation efflux system protein & $\begin{array}{c}\text { Methylobacterium } \\
\text { K. endophyticus }\end{array}$ \\
\hline $\mathrm{Cd}, \mathrm{Zn}$ & $c z c A$ & CzcA, proton antiport (CzcCBA chemiosmotic transporter) & Methylobacterium \\
\hline $\mathrm{Cd}, \mathrm{Zn}$ & $c z c B$ & $\mathrm{CzcB}$, proton antiport (CzcCBA chemiosmotic transporter) & $\begin{array}{l}\text { Methylobacterium } \\
\text { K. endophyticus }\end{array}$ \\
\hline $\mathrm{Cd}, \mathrm{Zn}$ & $\operatorname{cad} A 3$ & $\mathrm{Cd}^{2+}$-P-type exporting ATPase & $\begin{array}{l}\text { Methylobacterium } \\
\text { K. endophyticus }\end{array}$ \\
\hline $\mathrm{Zn}, \mathrm{Cd}$ & $z n t A$ & $\mathrm{Zn}^{2+}$-P-type exporting ATPase & $\begin{array}{l}\text { Methylobacterium } \\
\text { K. endophyticus }\end{array}$ \\
\hline $\mathrm{Zn}$ & Zur & Zur, Zinc uptake regulation protein & $\begin{array}{l}\text { Methylobacterium } \\
\text { K. endophyticus }\end{array}$ \\
\hline $\mathrm{Zn}$ & $z n u A$ & $\mathrm{ZnuA}, \mathrm{Zn}^{2+} \mathrm{ABC}$ transporter, periplasmic-binding protein & $\begin{array}{c}\text { Methylobacterium } \\
\text { K. endophyticus }\end{array}$ \\
\hline $\mathrm{Zn}$ & $z n u B$ & $\mathrm{ZnuB}, \mathrm{Zn}^{2+} \mathrm{ABC}$ transporter, inner membrane permease subunit & $\begin{array}{l}\text { Methylobacterium } \\
\text { K. endophyticus }\end{array}$ \\
\hline $\mathrm{Zn}$ & $z n u C$ & $\mathrm{ZnuC}, \mathrm{Zn}^{2+} \mathrm{ABC}$ transporter, ATP-binding subunit & $\begin{array}{l}\text { Methylobacterium } \\
\text { K. endophyticus }\end{array}$ \\
\hline
\end{tabular}

\subsection{Inoculation Experiment}

\subsubsection{Trace Element Concentrations in Soil}

The total TE concentrations of soil were: $223.4 \pm 9.74 \mathrm{mg} \mathrm{Zn} \mathrm{kg}^{-1}$ and 3.6 $\pm 0.18 \mathrm{mg} \mathrm{Cd} \mathrm{kg}^{-1}$. $\mathrm{CaCl}_{2}$-extractable $\mathrm{Zn}$ and $\mathrm{Cd}$ concentrations were $5.72 \pm 0.032$ and $0.13 \pm 0.008 \mathrm{mg} \mathrm{kg}^{-1}$, respectively. The total $\mathrm{Zn}$ and $\mathrm{Cd}$ concentrations exceeded the background values (59 and $0.69 \mathrm{mg} \mathrm{kg}^{-1}$, respectively) for sandy arable soil in Flanders legislation [50]. The nutrient concentrations in soil were: $1611 \pm 160.5 \mathrm{mg} \mathrm{kg}^{-1} \mathrm{Ca}$; $409.7 \pm 46.9 \mathrm{mg} \mathrm{kg}^{-1} \mathrm{~K} ; 695 \pm 83.1 \mathrm{mg} \mathrm{kg}^{-1} \mathrm{Mg} ; 66 \pm 6.0 \mathrm{mg} \mathrm{kg}^{-1} \mathrm{Cu}$.

\subsubsection{Plant Growth and Biomass Production}

In order to evaluate the possible effects of bacterial inoculation on the performance of Populus 'Dender' and 'Marke' cuttings, growth and photosystem II (PSII) efficiency were examined during the experiment. Growth was assessed by measuring shoot height, number of leaves and leaf area. Populus 'Marke' cuttings showed a significant increase in shoot length after inoculation with both Methylobacterium sp. CP3 and Kineococcus endophyticus CP19, compared to the control (Figure 2).

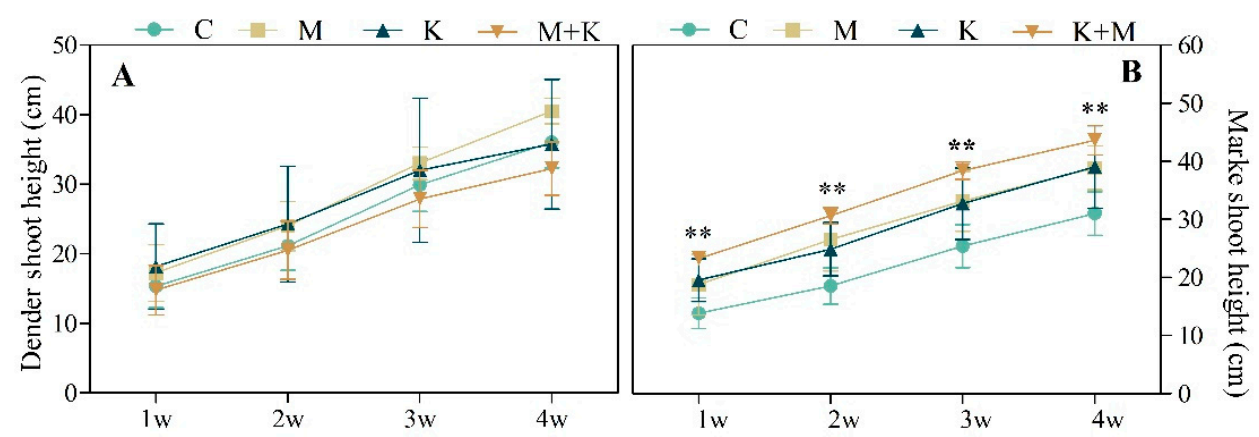

Figure 2. Shoot height in Populus 'Dender' (A) and Populus 'Marke' (B) cultivars detected during the 4-weeks inoculation experiment. Ctrl (control): non-inoculated cuttings; M: Methylobacterium sp. CP3 inoculation; K: Kineococcus endophyticus CP19 inoculation; M+K: Methylobacterium sp. CP3 and Kineococcus endophyticus CP19 inoculation. Bars represent \pm SD. ${ }^{* *} p<0.01$.

No significant differences were detected between inoculated and non-inoculated control cuttings, in terms of number of leaves and leaf area (Figure S3). Chlorophyll 
a fluorescence confirmed the good health status of the poplar cuttings. Both cultivars showed a good PSII performance: $\mathrm{F}_{\mathrm{v}} / \mathrm{F}_{\mathrm{m}}$, with values between 0.75 and 0.85 . In addition, no significant differences between the chlorophyll contents were detected between the different treatments (Figure 3).

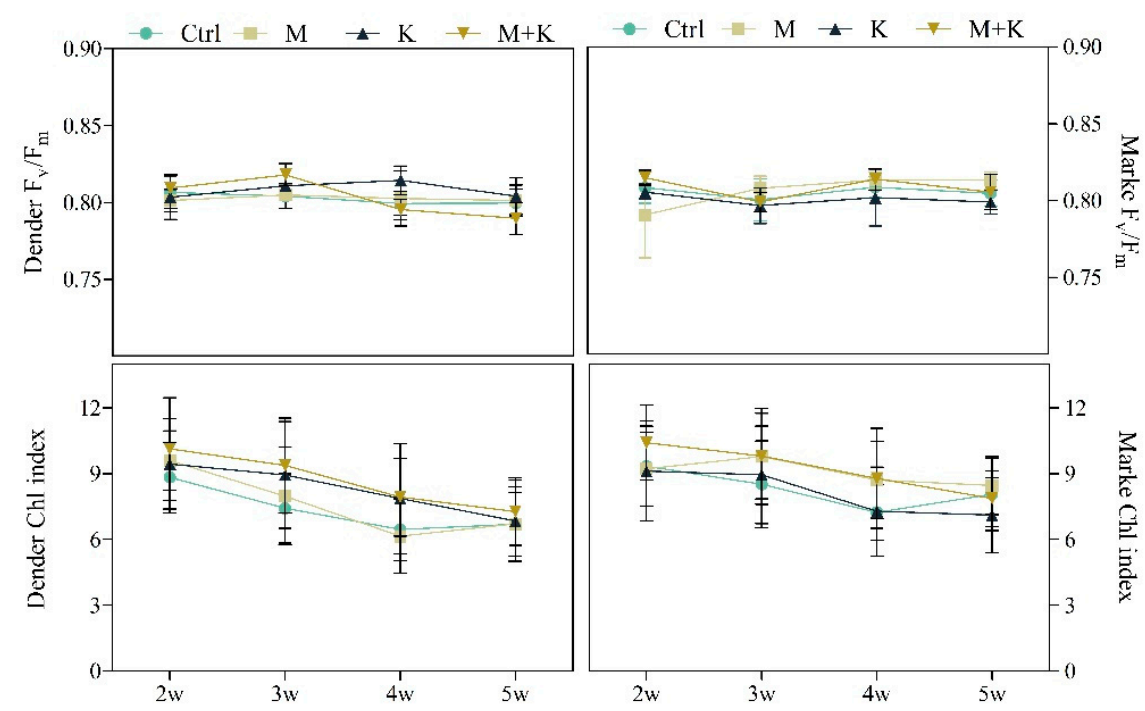

Figure 3. $\mathrm{F}_{\mathrm{v}} / \mathrm{F}_{\mathrm{m}}$ and chlorophyll content (Chl index) of leaves of Populus 'Dender and Populus 'Marke' determined during the 4-week experiment. Ctrl (control): Non-inoculated cuttings; M: Methylobacterium sp. CP3 inoculation; K: Kineococcus endophyticus CP19 inoculation; M+K: Methylobacterium sp. CP3 and Kineococcus endophyticus CP19 inoculation. Bars represent \pm SD.

In Figure 4, shoot and root dry weights of Populus 'Dender' and 'Marke' are presented. Shoot and roots were collected after 6 weeks of growth in trace element polluted soil. Bacterial inoculation did not have any significant effect on the dry weights of both poplar cultivars.
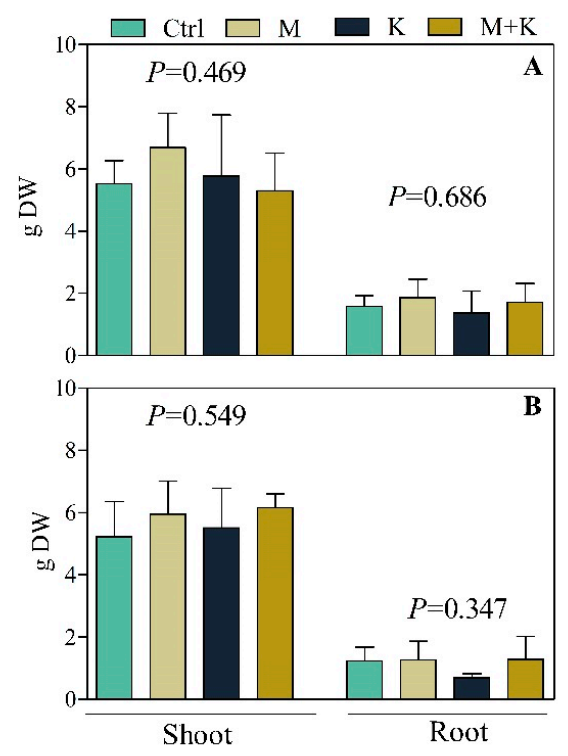

Figure 4. Dry weights (g) of shoots and roots of Populus 'Dender (A) and Populus 'Marke' (B) after 6 weeks of growth in trace elements polluted soil. Ctrl (control): non-inoculated cuttings; M: Methylobacterium sp. CP3 inoculation; K: Kineococcus endophyticus CP19 inoculation; M+K: Methylobacterium sp. CP3 and Kineococcus endophyticus CP19 inoculation. Statistical significance was tested with one-way ANOVA followed by Tukey's Multiple Comparison Test $(p \leq 0.05)$. 


\subsubsection{Element Concentrations in Plant Leaves and Roots}

After 6 weeks of growth in the polluted soil, the total $\mathrm{Cd}$ and $\mathrm{Zn}$ concentrations were determined in leaves and roots of both poplar cultivars. One-way ANOVA indicated no significant differences for $\mathrm{Cd}$ and $\mathrm{Zn}$ concentrations between inoculated plants and noninoculated ones, for both poplar cultivars (Figure 5), as well as for $\mathrm{Cd}$ and $\mathrm{Zn}$ translocation factors (Figure S4). Bioaccumulation factors (BAF, Figure 6) showed that the average values are higher than 1 for $\mathrm{Cd}$ and $\mathrm{Zn}$ in leaves and roots of cuttings of both cultivars. The concentration of $\mathrm{Zn}$ was significantly lower $(-40 \%)$ in roots of cuttings of cultivar 'Marke' inoculated with Methylobacterium sp. CP3 $(1.3 \pm 0.06)$, compared to the non-inoculated ones $(2.2 \pm 0.76)$.

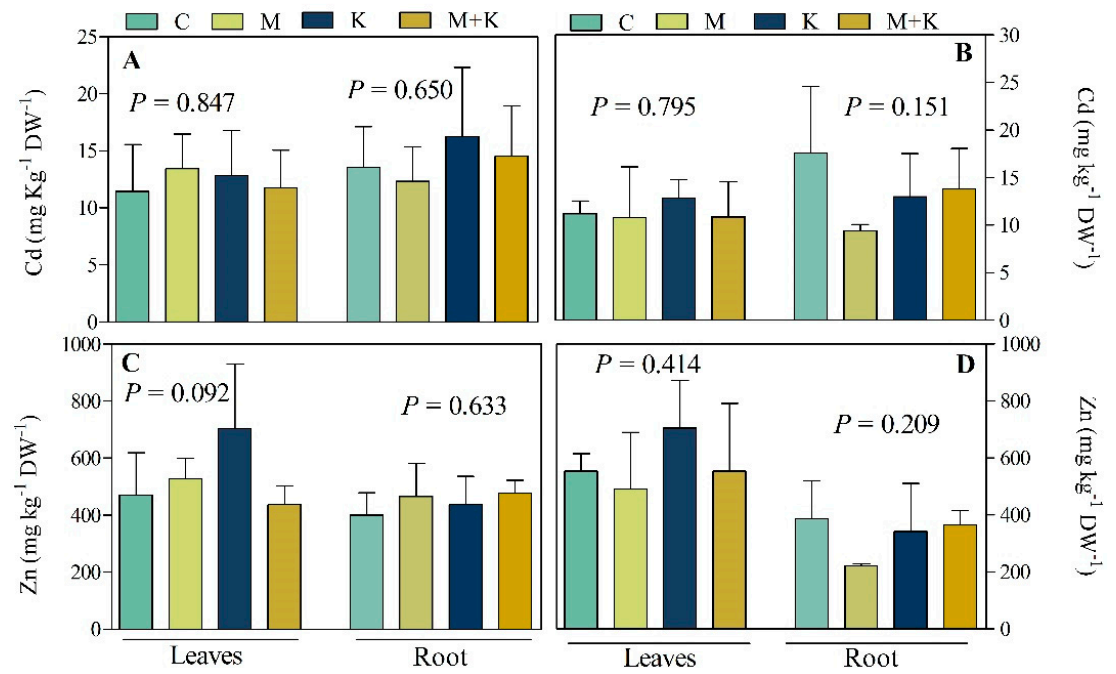

Figure 5. $\mathrm{Cd}$ and $\mathrm{Zn}$ concentrations ( $\mathrm{mg} \mathrm{kg}^{-1}$ dry weight) in leaves and roots of cuttings of Populus cultivars 'Dender' $(\mathbf{A}, \mathbf{C})$ and 'Marke' $(\mathbf{B}, \mathbf{D})$ after 6 weeks of growth in trace elements polluted soil. Ctrl (control): Non-inoculated cuttings; M: Methylobacterium sp. CP3 inoculation; K: Kineococcus endophyticus CP19 inoculation; M+K: Methylobacterium sp. CP3 and Kineococcus endophyticus CP19 inoculation. Statistical significance was determined with one-way ANOVA followed by Tukey's Multiple Comparison Test $(p<0.05)$.
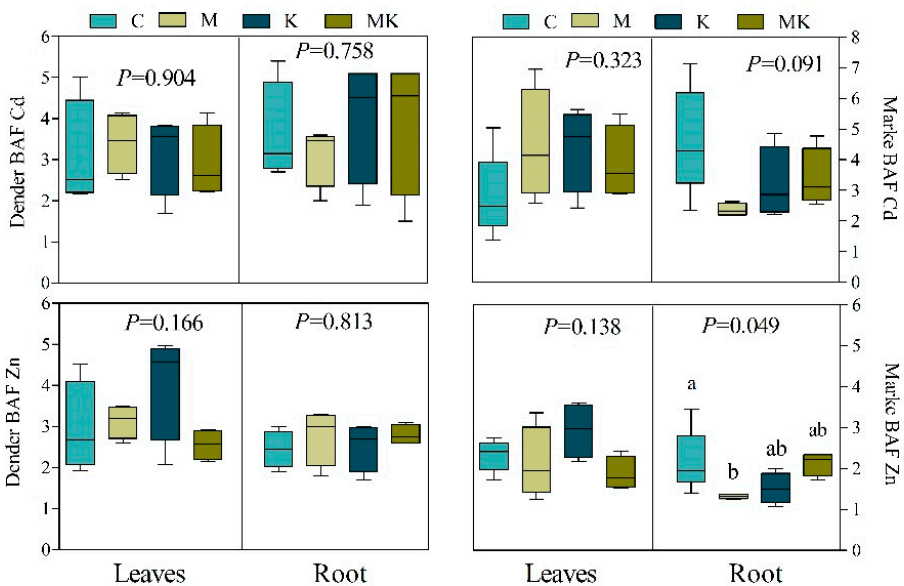

Figure 6. Bioaccumulation factors (BAF) for $\mathrm{Cd}$ and $\mathrm{Zn}$ calculated after 6 weeks of growth in trace elements polluted soil in leaves and roots of cuttings of the Populus cultivars 'Dender' and 'Marke'. Ctrl (control): non-inoculated cuttings; M: Methylobacterium sp. CP3 inoculation; K: Kineococcus endophyticus CP19 inoculation; M+K: Methylobacterium sp. CP3 and Kineococcus endophyticus CP19 inoculation. Statistical significance was determined with one-way ANOVA followed by Tukey's Multiple Comparison Test $(p \leq 0.05)$. 


\subsubsection{PCA Results}

PCA was performed to elucidate the poplar responses, in terms of growth and trace element accumulations, to inoculations with Methylobacterium sp. CP3 and K: Kineococcus endophyticus CP19 (Figure 7). The highest eigenvalues were achieved for two principal components which explained a $93 \%$ in total of the variability. The first principal component was determined by root biomass, $\mathrm{Tf}$ for $\mathrm{Cd}$ and $\mathrm{Zn}, \mathrm{BAF}$ for $\mathrm{Cd}$ and $\mathrm{Zn}$ in root and $\mathrm{BAF}$ for $\mathrm{Cd}$ in shoot, while the second one was represented by shoot biomass, BAF Cd in root, BAF $\mathrm{Zn}$ in shoot and shoot height. PCA revealed that the differentiation between inoculated and non-inoculated plants was mainly determined by these factors.

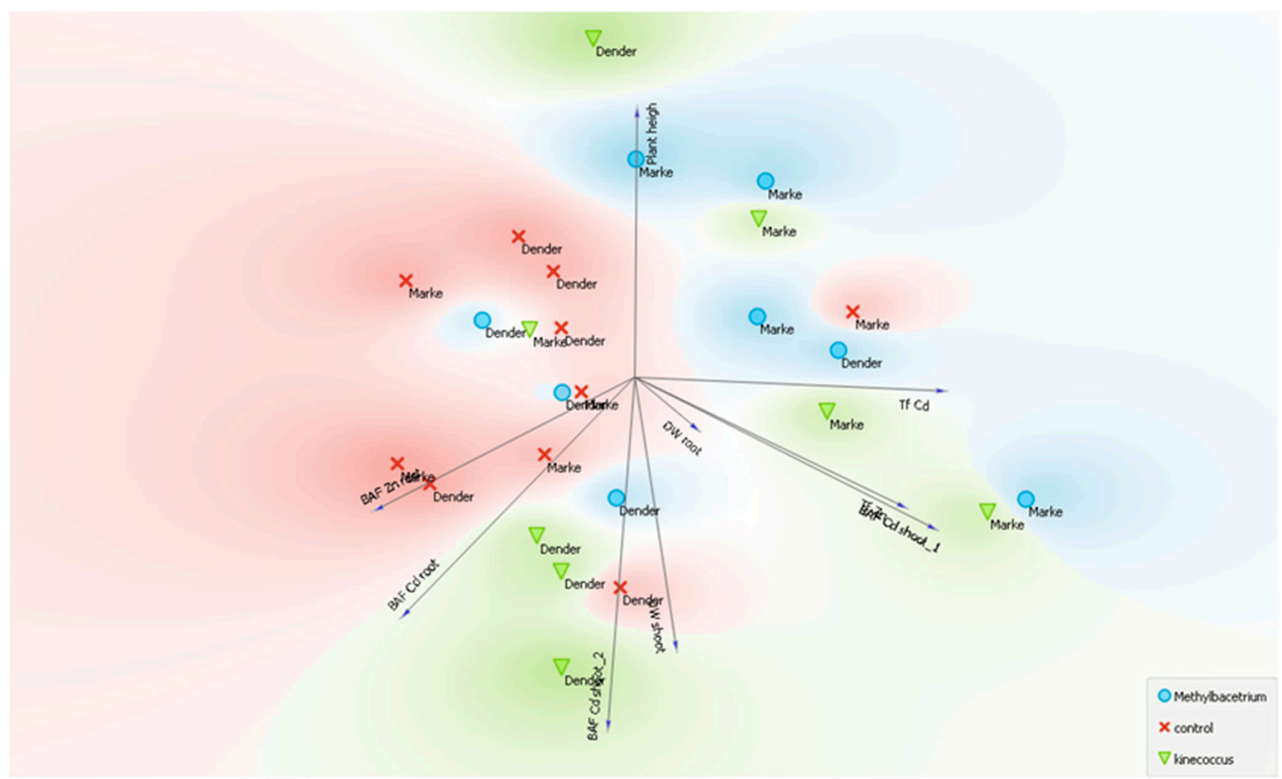

Figure 7. Principal component analysis computed with the main results of the experiment. Plant height refers to shoot length. Data obtained from different types of inoculation were reported in different colors and symbols. Control as red crosses (non-inoculated cuttings); Methylobacterium sp. CP3 inoculation as blue points; Kineococcus endophyticus CP19 inoculation as green triangle.

\subsubsection{Plant Nutritional Status}

Tables 3 and 4 show the micro-and macronutrient concentrations in the roots and leaves of cuttings after 6 weeks of growth in polluted soil. The Mg concentration was significantly higher $(+16 \%)$ in leaves of cuttings of the Populus 'Dender' cultivar inoculated with Methylobacterium sp. CP3 and Kineococcus endophyticus CP19, compared to non-inoculated cuttings (Table 3). In leaves of cuttings of the 'Marke' cultivar the Mg concentrations were higher $(+10 \%)$ when inoculated with with Methylobacterium sp. CP3 and Kineococcus endophyticus CP19, compared to non-inoculated cuttings (Table 4).

\subsubsection{Specific Automated Ribosomal Intergenic Spacer Analyses (ARISA)}

In order to evaluate the plant colonization by the two bacterial strains Methylobacterium sp. CP3 and Kineococcus endophyticus CP19, an ARISA analysis was performed (Figure S5). Heatmaps and the relative Pearson correlation analysis revealed the possible presence of Kineococcus endophyticus CP19 in some root samples of Populus 'Marke' (Figure S5A) and leaves of Populus 'Dender' cuttings (Figure S5B) inoculated with one or both strains. Methylbacterium sp. CP3 was not detected in none of the roots or leaves of both cultivars. 
Table 3. Micro- $(\mathrm{Cu}, \mathrm{Mn})$ and macronutrient $(\mathrm{Ca}, \mathrm{Mg}, \mathrm{K})$ concentrations $\left(\mathrm{mg} \mathrm{kg}^{-1} \mathrm{DW}\right)$ in leaves (L) and roots (R) of cuttings of the Populus cultivar 'Dender' after 6 weeks of growth in trace elements polluted soil. Ctrl (control): Non-inoculated cuttings; M: Methylobacterium sp. CP3 inoculation; K: Kineococcus endophyticus CP19 inoculation; M+K: Methylobacterium sp. CP3 and Kineococcus endophyticus CP19 inoculation. Statistical significance was determined with one-way ANOVA followed by Tukey's Multiple Comparison Test $(p \leq 0.05)$.

\begin{tabular}{ccccccc}
\hline & Organ & Ctrl & M & K & M + K & ANOVA \\
\hline $\mathbf{C u}$ & $L$ & $6 \pm 1.35$ & $8 \pm 1.5$ & $9 \pm 2.8$ & $6.3 \pm 0.8$ & 0.3019 \\
& $R$ & $33 \pm 9.9$ & $40 \pm 8.5$ & $34 \pm 7.5$ & $41 \pm 1.0$ & 0.051 \\
\hline $\mathbf{M n}$ & $L$ & $14.1 \pm 3.5$ & $16 \pm 2.6$ & $26 \pm 16.2$ & $16.5 \pm 1.4$ & 0.311 \\
& $R$ & $49 \pm 22.3$ & $81 \pm 11.9$ & $71 \pm 4.9$ & $73 \pm 4.8$ & 0.214 \\
\hline $\mathbf{C a}$ & $L$ & $8771 \pm 1574.1$ & $10167 \pm 1521.7$ & $11443 \pm 2510.3$ & $10712 \pm 728.6$ & 0.160 \\
& $R$ & $5007 \pm 667.8$ & $5015 \pm 823.0$ & $5130 \pm 597.7$ & $5062 \pm 684.1$ & 0.993 \\
\hline $\mathbf{M g}$ & $L$ & $1906 \pm 105.3 \mathrm{~b}$ & $2118 \pm 189.4 \mathrm{~b}$ & $2091 \pm 190.0 \mathrm{~b}$ & $2286 \pm 66.6 \mathrm{a}$ & $\mathbf{0 . 0 1 5}$ \\
& $R$ & $1532 \pm 133.6$ & $1400 \pm 129.9$ & $1451 \pm 181.1$ & $1402 \pm 49.8$ & 0.135 \\
\hline $\mathbf{K}$ & $L$ & $3374 \pm 306.2$ & $3792 \pm 562.3$ & $3765 \pm 828.9$ & $4229 \pm 456.8$ & 0.058 \\
& $R$ & $2960 \pm 524.4$ & $2636 \pm 462.9$ & $3699 \pm 701.5$ & $2553 \pm 431.1$ & 0.581 \\
\hline
\end{tabular}

Table 4. Micro- $(\mathrm{Cu}, \mathrm{Mn})$ and macronutrient $(\mathrm{Ca}, \mathrm{Mg}, \mathrm{K})$ concentrations $\left(\mathrm{mg} \mathrm{kg}^{-1} \mathrm{DW}\right)$ in leaves $(\mathrm{L})$ and roots $(\mathrm{R})$ of cuttings of the Populus cultivar 'Marke' after 6 weeks of growth on trace elements polluted soil. Ctrl (control): non-inoculated cuttings; M: Methylobacterium sp. CP3 inoculation; K: Kineococcus endophyticus CP19 inoculation; M+K: Methylobacterium sp. CP3 and Kineococcus endophyticus CP19 inoculation. Statistical significance was determined with one-way ANOVA followed by Tukey's Multiple Comparison Test $(p \leq 0.05)$.

\begin{tabular}{|c|c|c|c|c|c|c|}
\hline & & Ctrl & $\mathbf{M}$ & $\mathbf{K}$ & $\mathbf{M}+\mathbf{K}$ & ANOVA \\
\hline \multirow[t]{2}{*}{$\mathrm{Cu}$} & $L$ & $6 \pm 1.1$ & $6 \pm 0.8$ & $6 \pm 0.9$ & $6 \pm 1.2$ & 0.971 \\
\hline & $R$ & $28 \pm 11.3$ & $23 \pm 1.5$ & $22 \pm 6.1$ & $34 \pm 5.2$ & 0.1212 \\
\hline \multirow[t]{2}{*}{ Mn } & $L$ & $14.2 \pm 3.1$ & $16 \pm 4.1$ & $18 \pm 4.8$ & $16 \pm 3.6$ & 0.652 \\
\hline & $R$ & $35.3 \pm 23.5 \mathrm{ab}$ & $21 \pm 2.5 \mathrm{ab}$ & $22.5 \pm 7.6 \mathrm{~b}$ & $41.4 \pm 14.6 \mathrm{a}$ & 0.029 \\
\hline \multirow[t]{2}{*}{$\mathrm{Ca}$} & $L$ & $10767 \pm 948.1$ & $11099 \pm 1756.6$ & $12904 \pm 1732.7$ & $11661 \pm 956.3$ & 0.233 \\
\hline & $R$ & $4284 \pm 765.5 \mathrm{ab}$ & $3880 \pm 231.4 \mathrm{ab}$ & $3630 \pm 410.9 b$ & $4842 \pm 283.4 \mathrm{a}$ & 0.022 \\
\hline \multirow[t]{2}{*}{$\mathrm{Mg}$} & $L$ & $2030 \pm 129.6 a$ & $2203 \pm 221.3 a b$ & $2196 \pm 67.6 \mathrm{ab}$ & $2267 \pm 57.9 b$ & 0.029 \\
\hline & $R$ & $1442 \pm 2018.4$ & $1269 \pm 71.9$ & $1282 \pm 119.4$ & $1502 \pm 176.7$ & 0.135 \\
\hline \multirow[t]{2}{*}{ K } & $L$ & $3799 \pm 429.0$ & $3818 \pm 661.8$ & $4134 \pm 366.3$ & $4442 \pm 497.3$ & 0.241 \\
\hline & $R$ & $2941 \pm 514.0$ & $2435 \pm 461.5$ & $2354 \pm 56.2$ & $2339 \pm 320.2$ & 0.107 \\
\hline
\end{tabular}

\subsection{Discussion}

The study of the seed microbiome of metallophytes revealed interesting endophytes, demonstrating high TE tolerance and plant growth promotion properties [28]. A bioaugmentation approach using endophytes previously isolated from metallophytes, can improve the tolerance of plants to trace elements [27]. Therefore, two seed endophytic bacteria isolated from C. pumila colonizing a mining area in Mexico, were characterized and inoculated on cuttings of two poplar cultivars growing in TE polluted soil.

In vitro tests indicated that the two seed endophytes possess potential plant growth promoters (Table 1). Both Methylobacterium sp. CP3 and Kineococcus endophyticus CP19 can synthetize the plant hormone indole-3-acetic acid (IAA). Some of the effects of IAA production are positively related to root elongation and the numbers of root branches and hairs, which can lead to a higher water and nutrient uptake potential [32]. The production of IAA by bacteria is mostly promoted by the release of certain molecules (amino acids, sugar and organic acids) by the host plants [51]. In addition, Methylobacterium sp. CP3 showed the ability to mineralize phytate in vitro, most likely through the production of organic and inorganic compounds as well as phosphatase enzymes [52,53], suggesting some capability to convert insoluble phosphorous into an available form for plants [54]. 
Therefore, Methylobacterium sp. CP3 can be considered as a phosphobacteria, like other bacterial strains belonging to the genera Pseudomonas, Serratia, Pantoea, Bacillus, Agrobacterium and Microccocus $[55,56]$. These in vitro plant growth promoting traits have been verified in an in vivo experiment in which cuttings of Populus 'Marke' were inoculated with Methylobacterium sp. CP3 and Kineococcus endophyticus CP19. In vitro, Methylobacterium sp. $\mathrm{CP} 3$ could grow on 0.4 and $0.8 \mathrm{mM} \mathrm{Cd}$, as well as 0.6 and $1 \mathrm{mM} \mathrm{Zn}$ supplemented media (Table 1), confirming the endophyte tolerance for these TEs [29]. Kineococcus endophyticus CP19 showed only tolerance for $\mathrm{Zn}(0.6$ and $1 \mathrm{mM})$. Earlier, copper tolerance has been reported in the genus Kineococcus [57]. This study increased the knowledge bank and applicability for such endophyte.

Generally, different mechanisms can be involved in bacteria TE defense, including the reduction of the TE uptake through enzymatic transformation [58]. Redox reactions may decrease the mobility and/or toxicity of TE (e.g., Cr) and methylation enables the transformation of some TE into a gaseous state, due to the volatility of the methylated TE [59]. Other TE tolerance mechanisms in bacteria include the sequestration of TE as physical adsorption of $\mathrm{Zn}$ and $\mathrm{Cd}$ through binding sites [60], for instance carboxyl groups in gramnegative (e.g., Methylobacterium sp. CP3) or involving extracellular polymer substances (EPS). Such high molecular weight polyanionic polymers which can contribute to metal immobilization, outside the bacterial cell [61-63]. The EPS properties to bind metals, i.e. $\mathrm{Cu}$ and $\mathrm{Pb}$, have been studied in other bacterial species of the genus Methylobacterium [64]. In our study, the capability of Methylobacterium sp. CP3 to interact with trace elements was highlighted via SEM-EDX imaging (Figures S1 and S2) and the gene annotation (Table 2). Bacteria can actively transport ions outside the membrane through ion antiporter systems and the subsequent increase in $\mathrm{pH}$ leads to the precipitation of TE as insoluble forms, e.g., carbonates $[65,66]$. In our study, the presence of $\mathrm{Cd}$ and $\mathrm{Zn}$ in/on the bacterial surfaces can be related to the presence of $c z c$ ion efflux system, protecting the bacterial cell in a TE polluted environment. In fact, the $c z c$ is an ion antiporter efflux system and the $c z c$-mediated efflux of cations, followed by the precipitation of TE carbonates in bacteria walls, has been observed in bacterial cultures, growing in high TE concentrations $[67,68]$. The dissimilar responses to high TE concentrations amongst studied endophytes could be related to the different TE resistance systems (Table 2). The ability of Methylobacterium sp. $\mathrm{CP} 3$ to tolerate high concentration of $\mathrm{Zn}$ and $\mathrm{Cd}$ could reflect the presence of encoded $\mathrm{CzcA}$, $C z c B$ and $C z c D$ proteins, while Kineccoccus endophyticus $C P 19$ encoded $C z c B$ and $C z c D$. The $C z c A$ protein is mainly involved in $C d$ and $\mathrm{Zn}$ resistance and coupled with $C z c B$ and $C z c D$ contributes to the efflux of TE outside the bacterial cell [69]. The $\mathrm{Zn}$ tolerance detected at high $\mathrm{Zn}$ concentrations in both bacterial strains could be related to the encoded $\mathrm{ZnuABC}$ systems (Table 2), mainly involved in $\mathrm{Zn}$ homeostasis [70]. However, deeper investigation into this area is required to fully unravel the specific mechanisms adopted by the studied bacteria, especially influenced by growing media. In fact, the composition of the medium can affect the detoxification strategies adopted by bacteria to cope with non-physiological concentrations of TE, as investigated for Cd by Holmes [37].

In an in vivo experiment, the inoculation with Methylobacterium sp. CP3 led to a decrease of the bioaccumulation factor of $\mathrm{Zn}$ in roots of cuttings of the Populus 'Marke' cultivar (Figure 6). Previous studies also reported a lower bioaccumulation of $\mathrm{Zn}$ in tomato plants inoculated with other species of the genus Methylobacterium [71], and in Spartia maritima inoculated with other TE tolerant and PGP endophytes [72]. Due to such a protective role through the reduction in $\mathrm{Zn}$ uptake, Methylobacterium sp. CP3 may confer to the Populus cultivar 'Marke' an excluder strategy, thus also conferring the ability to grow in soils with $\mathrm{Zn}$ concentrations that are phytotoxic for non-inoculated plants [73]. Trace element pollution in soils can lead to nutrient deficiency in plants, as TE ions and essential nutrients are taken up by the same plant transporter proteins [74]. We observed higher $\mathrm{Mg}$ concentrations in the leaves in both poplar cultivars, inoculated with both Methylobacterium sp. CP3 and Kineococcus endophyticus CP19 (Tables 3 and 4). Magnesium is the central element in chlorophyll molecules and an important co-factor in several enzymes [75]. 
Moreover, the role of $\mathrm{Mg}$ in alleviating TE toxicity has been demonstrated. This element is involved in plant protection mechanisms that include synthesis of organic acids and sequestration of TE ions. In addition, maintaining a good $\mathrm{Mg}$ nutritional status in plants is effective to limit photooxidative damage due to ROS production under abiotic stress [76]. These positive effects of Methylobacterium sp. CP3 and Kineccoccus endophyticus CP19 on the $\mathrm{Mg}$ concentration in leaves might increase the tolerance of poplar to TE exposure in the long-term.

The ARISA confirmed the presence of the inoculated Kineococcus endophyticus CP19 in certain of the plant tissues, especially in Populus 'Marke' (Figure S5). The increased plant growth and nutrient uptake in Populus 'Marke' could be related to a direct effect of Kineococcus endophyticus CP19 in such cultivar. In Populus 'Dender', the effects of inoculation on trace element bioaccumulation and nutrient uptake (Figure 7; Tables 3 and 4) are observed, although the presence of the inoculated endophytes was not confirmed. More extensive and robust investigations of inoculation success, using specific primers, is required. This will also hypothesize the eventual indirect effects of inoculation.

\subsection{Conclusions}

Methylobacterium sp. CP3 and Kineococcus endophyticus CP19 are seed endophytes, whose tolerance and close physical interaction with $\mathrm{Zn}$ and $\mathrm{Cd}$ have been confirmed in this study. In addition, the ability to produce IAA by both strains and the phytate mineralization by Methylbacterium sp. CP3 were demonstrated in vitro. The inoculation of both bacteria positively affected the growth of the Populus cultivar 'Marke'. This study also puts forward Methylobacterium sp. CP3 as a possible candidate for the increase in $\mathrm{Zn}$ tolerance of the host plant. Apparently, $\mathrm{Zn}$ uptake is lowered, while the $\mathrm{Mg}$ concentration in poplar leaves is enhanced by inoculation of both Methylobacterium sp. CP3 and Kineococcus endophyticus CP19, already after six weeks of plant growth. The improvements in TE tolerance of poplar in the long-term, as well as the inoculation success need to be more deeply investigated. In addition, the link between the bacteria TE tolerance and the presence of certain genes needs to be clarified through transcriptomic analyses.

Supplementary Materials: The following are available online at https:/ / www.mdpi.com/article/10 .3390 /agronomy11101987/s1, Figure S1: SEM image of Methylobacterium sp. CP3 culture and relative EDX spectra in a $0.8 \mathrm{mM}$ Cd containing medium, Figure S2: SEM image of Methylobacterium sp. CP3 culture and relative EDX spectra in $1 \mathrm{mM}$ Zn containing medium, Figure S3: Number of leaves and leaf area in Populus 'Dender and Populus 'Marke' cul-tivars detected during the 4-weeks inoculation experiment, Figure S4: Translocation factors for $\mathrm{Cd}$ and $\mathrm{Zn}$ calculated for cuttings of the Populus cultivars 'Dender' and 'Marke' after 6 weeks of growth in trace elements polluted soil, Figure S5: Heatmaps derived by ARISA analysis for Pop-ulus 'Marke' roots and 'Dender leaves.

Author Contributions: Conceptualization, S.T.; J.V. and L.S.; methodology, S.T. and J.V.; software, J.D.; validation, S.T.; J.V. and L.S.; formal analysis, F.V.; J.D.; V.I.; S.S. and A.S.; investigation, F.V.; V.I.; S.S.; J.D. and A.S.; resources, S.T.; J.V. and J.D.; data curation, F.V., V.I. and S.T.; writing-original draft preparation F.V.; writing—review and editing F.V.; V.I.; A.S.; J.V. and L.S.; supervision, S.T.; J.V. and L.S.; All authors have read and agreed to the published version of the manuscript.

Funding: This research has been supported by the UHasselt Methusalem project 08M03VGRJ.

Data Availability Statement: Not applicable.

Conflicts of Interest: The authors declare no conflict of interest.

\section{References}

1. Wuana, R.A.; Okieimen, F.E. Heavy metals in contaminated soils: A review of sources, chemistry, risks and best available strategies for remediation. ISRN Ecol. 2011, 2011, 1-20. [CrossRef]

2. He, Z.; Shentu, J.; Yang, X.; Baligar, V.C.; Zhang, T.; Stoffella, P.J. Heavy TE contamination of soils: Sources, indicators, and assessment. Environ. Dev. Sustain. 2015, 9, 17-18.

3. Tóth, G.; Hermann, T.; Da Silva, M.R.; Montanarella, L. Heavy metals in agricultural soils of the European Union with implications for food safety. Environ. Int. 2016, 88, 299-309. [CrossRef] [PubMed] 
4. Vangronsveld, J.; Van Assche, F.; Clijsters, H. Reclamation of a bare industrial area contaminated by non-ferrous metals-In situ metal immobilization and revegetation. Environ. Pollut. 1995, 87, 51-59. [CrossRef]

5. Hogervorst, J.; Plusquin, M.; Vangronsveld, J.; Nawrot, T.; Cuypers, A.; Van Hecke, E.; Roels, H.A.; Carleer, R.; Staessen, J.A. House dust as possible route of environmental exposure to cadmium and lead in the adult general population. Environ. Res. 2007, 103, 30-37. [CrossRef]

6. Vangronsveld, J.; Herzig, R.; Weyens, N.; Boulet, J.; Adriaensen, K.; Ruttens, A.; Thewys, T.; Vassilev, A.; Meers, E.; Nehnevajova, E.; et al. Phytoremediation of contaminated soils and groundwater: Lessons from the field. Environ. Sci. Pollut. Res. 2009, 16, 765-794. [CrossRef] [PubMed]

7. Witters, N.; Van Slycken, S.; Ruttens, A.; Adriaensen, K.; Meers, E.; Meiresonne, L.; Tack, F.M.; Thewys, T.; Laes, E.; Vangronsveld, J. Short-rotation coppice of willow for phytoremediation of a TE-contaminated agricultural area: A sustainability assessment. Bioenergy Res. 2009, 2, 144-152. [CrossRef]

8. Janssen, J.; Weyens, N.; Croes, S.; Beckers, B.; Meiresonne, L.; Van Peteghem, P.; Carleer, R.; Vangronsveld, J. Phytoremediation of TE contaminated soil using willow: Exploiting plant-associated bacteria to improve biomass production and TE uptake. Int. J. Phytoremed. 2015, 17, 1123-1136. [CrossRef] [PubMed]

9. Thijs, S.; Witters, N.; Janssen, J.; Ruttens, A.; Weyens, N.; Herzig, R.; Mench, M.; Van Slycken, S.; Meers, E.; Meiresonne, L.; et al. Tobacco, sunflower and high biomass SRC clones show potential for trace TE phytoextraction on a moderately contaminated field site in Belgium. Front. Plant Sci. 2018, 9, 1879. [CrossRef]

10. Sebastiani, L.; Scebba, F.; Tognetti, R. Heavy metal accumulation and growth responses in poplar clones Eridano (Populus deltoides $\times$ maximowiczii) and I-214 (P. $\times$ euramericana) exposed to industrial waste. Environ. Exper. Bot. 2004, 52, 79-88. [CrossRef]

11. Giachetti, G.; Sebastiani, L. TE accumulation in poplar plant grown with industrial wastes. Chemosphere 2006, 64, 446-454. [CrossRef] [PubMed]

12. Pajević, S.; Borišev, M.; Nikolić, N.; Krstić, B.; Pilipović, A.; Orlović, S. Phytoremediation capacity of poplar (Populus spp.) and willow (Salix spp.) clones in relation to photosynthesis. Arch. Biol. Sci. 2009, 61, 239-247. [CrossRef]

13. Marmiroli, M.; Pietrini, F.; Maestri, E.; Zacchini, M.; Marmiroli, N.; Massacci, A. Growth, physiological and molecular traits in Salicaceae trees investigated for phytoremediation of heavy TEs and organics. Tree Physiol. 2011, 31, 1319-1334. [CrossRef] [PubMed]

14. FAO. Poplars and Other Fast-Growing Trees-Renewable Resources for Future Green Economies. Synthesis of Country Progress Reports. In Proceedings of the 25th Session of the International Poplar Commission, Berlin, Germany, 13-16 September 2016; Working Paper IPC/15; Forestry Policy and Resources Division, FAO: Rome, Italy, 2016; Available online: http://www.fao.org/forestry/ ipc2016/en/ (accessed on 25 January 2021).

15. Ruttens, A.; Boulet, J.; Weyens, N.; Smeets, K.; Adriaensen, K.; Meers, E.; Van Slycken, S.; Tack, F.M.G.; Meiresonne, L.; Thewys, T.; et al. Short rotation coppice culture of willows and poplars as energy crops on metal contaminated agricultural soils. Int. J. Phytoremed. 2011, 13, 194-207. [CrossRef]

16. Mola-Yudego, B.; Díaz-Yáñez, O.; Dimitriou, I. How much yield should we expect from fast-growing plantations for energy? Divergences between experiments and commercial willow plantations. BioEnergy Res. 2015, 8, 1769-1777. [CrossRef]

17. Mastretta, C.; Barac, T.; Vangronsveld, J.; Newman, L.; Taghavi, S.; Lelie, D.V.D. Endophytic bacteria and their potential application to improve the phytoremediation of contaminated environments. Biotechnol. Genet. Eng. Rev. 2006, 23, 175-188. [CrossRef]

18. Glick, B.R. Using soil bacteria to facilitate phytoremediation. Biotechnol. Adv. 2010, 28, 367-374. [CrossRef]

19. Weyens, N.; van der Lelie, D.; Taghavi, S.; Vangronsveld, J. Phytoremediation: Plant-endophyte partnerships take the challenge. Curr. Opin. Biotechnol. 2009, 20, 248-254. [CrossRef]

20. Ahemad, M.; Kibret, M. Recent trends in microbial biosorption of heavy TEs: A review. Int. J. Biochem. Mol. Biol. 2013, 1, 19-26. [CrossRef]

21. Herrera, S.D.; Grossi, C.; Zawoznik, M.; Groppa, M.D. Wheat seeds harbour bacterial endophytes with potential as plant growth promoters and biocontrol agents of Fusarium graminearum. Microbiol. Res. 2016, 186, 37-43. [CrossRef]

22. Khalaf, E.M.; Raizada, M.N. Taxonomic and functional diversity of cultured seed associated microbes of the cucurbit family. BMC Microbiol. 2016, 16, 131. [CrossRef] [PubMed]

23. Hardoim, P.R.; van Overbeek, L.S.; van Elsas, J.D. Properties of bacterial endophytes and their proposed role in plant growth. Trends Microbiol. 2008, 16, 463-471. [CrossRef] [PubMed]

24. Pitzschke, A. Developmental Peculiarities and Seed-Borne Endophytes in Quinoa: Omnipresent, Robust Bacilli Contribute to Plant Fitness. Front. Microbiol. 2016, 7, 2. [CrossRef] [PubMed]

25. Truyens, S.; Beckers, B.; Thijs, S.; Weyens, N.; Cuypers, A.; Vangronsveld, J. Cadmium-induced and trans-generational changes in the cultivable and total seed endophytic community of Arabidopsis thaliana. Plant Biol. 2016, 18, 376-381. [CrossRef] [PubMed]

26. Sánchez-López, A.S.; Thijs, S.; Beckers, B.; González-Chávez, M.C.; Weyens, N.; Carrillo-González, R.; Vangronsveld, J. Community structure and diversity of endophytic bacteria in seeds of three consecutive generations of Crotalaria pumila growing on metal mine residues. Plant Soil 2018, 422, 51-66. [CrossRef]

27. Li, H.; Parmar, S.; Sharma, V.K.; White, J.F. Seed Endophytes and Their Potential Applications. In Seed Endophytes; Verma, S., White, J., Jr., Eds.; Springer: Cham, Switzerland, 2019; pp. 35-54. 
28. Sánchez-López, A.S.; González-Chávez, M.D.C.A.; Carrillo-González, R.; Vangronsveld, J.; Díaz-Garduño, M. Wild flora of mine tailings: Perspectives for use in phytoremediation of potentially toxic elements in a semi-arid region in Mexico. Int. J. Phytoremed. 2015, 17, 476-484. [CrossRef] [PubMed]

29. Sánchez-López, A.; Pintelon, I.; Stevens, V.; Imperato, V.; Timmermans, J.P.; González-Chávez, C.; Carrillo-González, R.; Van Hamme., J.; Vangronsveld, J.; Thijs, S. Seed endophyte microbiome of Crotalaria pumila unpeeled: Identification of plant-beneficial Methylobacteria. Int. J. Mol. Sci. 2018, 19, 291. [CrossRef] [PubMed]

30. Mergeay, M.; Nies, D.; Schlegel, H.; Gerits, J.; Charles, P.; Van Gijsegem, F. Alcaligenes eutrophus CH34 is a facultative chemolithotroph with plasmid-bound resistance to heavy TEs. J. Bacteriol. Res. 1985, 162, 328-334. [CrossRef]

31. Patten, C.L.; Glick, B.R. Role of Pseudomonas putida indoleacetic acid in development of the host plant root system. Appl. Environ. Microbiol. 2002, 68, 3795-3801. [CrossRef]

32. Jorquera, M.A.; Hernández, M.T.; Rengel, Z.; Marschner, P.; de la Luz Mora, M. Isolation of culturable phosphobacteria with both phytate-mineralization and phosphate-solubilization activity from the rhizosphere of plants grown in a volcanic soil. Bio. Fertil. Soils 2008, 44, 1025-1034. [CrossRef]

33. Schwyn, B.; Neilands, J. Universal chemical assay for the detection and determination of siderophores. Anal. Biochem. 1987, 160, 47-56. [CrossRef]

34. Schlegel, H.G.; Cosson, J.P.; Baker, A.J.M. Nichel-hyperaccumulating plants provide a nichel for nichel-resistant bacteria. Bot. Acta 1961, 194, 18-25.

35. Cunningham, J.E.; Kuiack, C. Production of citric and oxalic acids and solubilization of calcium phosphate by Penicillium bilaii. Appl. Environ. Microbiol. 1992, 58, 1451-1458. [CrossRef] [PubMed]

36. Holmes, J.D.; Smith, P.R.; Evans-Gowing, R.; Richardson, D.J.; Russell, D.A.; Sodeau, J.R. Energy-dispersive X-ray analysis of the extracellular cadmium sulfide crystallites of Klebsiella aerogenes. Arch. Microbiol. 1995, 163, 143-147. [CrossRef] [PubMed]

37. Overbeek, R.; Olson, R.; Pusch, G.D.; Olsen, G.J.; Davis, J.J.; Disz, T.; Edwards, T.A.; Gerdes, S.; Parrello, B.; Shukla, M.; et al. The SEED and the Rapid Annotation of microbial genomes using Subsystems Technology (RAST). Nucleic Acids Res. 2014, 42, D206-D214. [CrossRef] [PubMed]

38. Tatusova, T.; DiCuccio, M.; Badretdin, A.; Chetvernin, V.; Nawrocki, E.P.; Zaslavsky, L.; Lomsadze, A.; Pruitt, K.D.; Borodovsky, M.; Ostell, J. NCBI prokaryotic genome annotation pipeline. Nucleic Acids Res. 2016, 44, 6614-6624. [CrossRef]

39. Vallenet, D.; Labarre, L.; Rouy, Z.; Barbe, V.; Bocs, S.; Cruveiller, S.; Lajus, A.; Pascal, G.; Scarpelli, C.; Médigue, C. MaGe: A microbial genome annotation system supported by synteny results. Nucleic Acids Res. 2006, 34, 53-65. [CrossRef]

40. Tatusov, R.L.; Galperin, M.Y.; Natale, D.A.; Koonin, E.V. The COG database: A tool for genome-scale analysis of protein functions and evolution. Nucleic Acids Res. 2000, 28, 33-36. [CrossRef]

41. Kanehisa, M.; Goto, S.; Sato, Y.; Furumichi, M.; Tanabe, M. KEGG for integration and interpretation of large-scale molecular data sets. Nucleic Acids Res. 2012, 40, D109-D114. [CrossRef]

42. Caspi, R.; Billington, R.; Fulcher, C.A.; Keseler, I.M.; Kothari, A.; Krummenacker, M.; Latendresse, M.; Midford, P.E.; Ong, Q.; Ong, W.K.; et al. The MetaCyc database of metabolic pathways and enzymes. Nucleic Acids Res. 2017, 46, D633-D639. [CrossRef]

43. Meers, E.; Samson, R.; Tack, F.; Ruttens, A.; Vandegehuchte, M.; Vangronsveld, J.; Verloo, M. Phytoavailability assessment of heavy metals in soils by single extractions and accumulation by Phaseolus vulgaris. Environ. Exp. Bot. 2007, 60, 385-396. [CrossRef]

44. Cardinale, M.; Brusetti, L.; Quatrini, P.; Borin, S.; Puglia, A.M.; Rizzi, A.; Zanardini, E.; Sorlini, C.; Corselli, C.; Daffonchio, D. Comparison of different primer sets for use in automated ribosomal intergenic spacer analysis of complex bacterial communities. Appl. Environ. Microbiol. 2004, 70, 6147-6156. [CrossRef] [PubMed]

45. Michelland, R.J.; Dejean, S.; Combes, S.; Fortun-Lamothe, L.; Cauquil, L. StatFingerprints: A friendly graphical interface program for processing and analysis of microbial fingerprint profiles. Mol. Ecol. Res. 2009, 9, 1359-1363. [CrossRef]

46. U.S. EPA. Method 3050B: Acid Digestion of Sediments, Sludges, and Soils; Revision 2; U.S. EPA: Washington, DC, USA, 1996.

47. U.S. EPA. Method 3051A Acid Digestion of Sediments, Sludge, and Soils; U.S. EPA: Washington, DC, USA, 1994.

48. Pandey, S.; Rai, R.; Rai, L.C. Biochemical and Molecular Basis of Arsenic Toxicity and Tolerance in Microbes and Plants. In Handbook of Arsenic Toxicology; Flora, S.J.S., Ed.; Academic Press: Cambridge, MA, USA, 2015; pp. 627-674.

49. De Temmerman, L.; Vanongeval, L.; Boon, W.; Hoenig, M.; Geypens, M. Heavy metal content of arable soils in Northern Belgium. Water Air Soil Pollut. 2003, 148, 61-76. [CrossRef]

50. Zhao, Y. Auxin biosynthesis and its role in plant development. Ann. Rev. Plant Biol. 2010, 61, 49-64. [CrossRef]

51. Lin, T.F.; Huang, H.I.; Shen, F.T.; Young, C.C. The protons of gluconic acid are the major factor responsible for the dissolution of tricalcium phosphate by Burkholderia cepacia CC-Al74. Bioresour. Technol. 2006, 97, 957-960. [CrossRef]

52. Kohler, J.; Caravaca, F.; Carrasco, L.; Roldan, A. Interactions between a plant growth-promoting rhizobacterium, an AM fungus and a phosphate-solubilising fungus in the rhizosphere of Lactuca sativa. Appl. Soil Ecol. 2007, 35, 480-487. [CrossRef]

53. Rodríguez, H.; Fraga, R.; Gonzalez, T.; Bashan, Y. Genetics of phosphate solubilization and its potential applications for improving plant growth-promoting bacteria. Plant Soil 2006, 287, 15-21. [CrossRef]

54. Rodríguez, H.; Fraga, R. Phosphate solubilizing bacteria and their role in plant growth promotion. Biotechnol. Adv. 1999, 17, 319-339. [CrossRef]

55. Viruel, E.; Lucca, M.E.; Siñeriz, F. Plant growth promotion traits of phosphobacteria isolated from Puna, Argentina. Arch. Microbiol. 2011, 193, 489-496. [CrossRef] [PubMed] 
56. Bagwell, C.E.; Hixson, K.K.; Milliken, C.E.; Lopez-Ferrer, D.; Weitz, K.K. Proteomic and physiological responses of Kineococcus radiotolerans to copper. PLOS ONE 2010, 5, e12427. [CrossRef]

57. Ojuederie, O.; Babalola, O. Microbial and plant-assisted bioremediation of heavy metal polluted environments: A review. Int. J. Environ. Res. Public Health 2017, 14, 1504. [CrossRef]

58. Etesami, H. Bacterial mediated alleviation of heavy metal stress and decreased accumulation of metals in plant tissues: Mechanisms and future prospects. Ecotoxicol. Environ. Saf. 2018, 147, 175-191. [CrossRef] [PubMed]

59. Gadd, G.M. Biosorption: Critical review of scientific rationale, environmental importance and significance for pollution treatment. J. Chem. Technol. Biotechnol. 2009, 84, 13-28. [CrossRef]

60. Pal, A.; Paul, A.K. Microbial extracellular polymeric substances: Central elements in heavy metal bioremediation. Indian J. Microbiol. 2008, 48, 49. [CrossRef] [PubMed]

61. Wei, X.; Fang, L.; Cai, P.; Huang, Q.; Chen, H.; Liang, W.; Rong, X. Influence of extracellular polymeric substances (EPS) on Cd adsorption by bacteria. Environ. Pollut. 2011, 159, 1369-1374. [CrossRef] [PubMed]

62. Muthu, M.; Wu, H.F.; Gopal, J.; Sivanesan, I.; Chun, S. Exploiting microbial polysaccharides for biosorption of trace elements in aqueous environments-Scope for expansion via nanomaterial intervention. Polymers 2017, 9, 721. [CrossRef]

63. Kim, S.Y.; Kim, J.H.; Kim, C.J.; Oh, D.K. TE adsorption of the polysaccharide produced from Methylobacterium organophilum. Biotechnol. Lett. 1996, 18, 1161-1164. [CrossRef]

64. Kumari, D.; Qian, X.Y.; Pan, X.; Achal, V.; Li, Q.; Gadd, G.M. Microbially-induced carbonate precipitation for immobilization of toxic TEs. Adv. Appl. Microbiol. 2016, 94, 79-108. [PubMed]

65. Igiri, B.E.; Okoduwa, S.I.; Idoko, G.O.; Akabuogu, E.P.; Adeyi, A.O.; Ejiogu, I.K. Toxicity and bioremediation of heavy TEs contaminated ecosystem from tannery wastewater: A review. J. Toxicol. 2018, 2018, 1-16. [CrossRef] [PubMed]

66. Diels, L.; Dong, Q.; van der Lelie, D.; Baeyens, W.; Mergeay, M. The czc operon of Alcaligenes eutrophus CH34: From resistance mechanism to the removal of heavy metals. J. Ind. Microbiol. Biotechnol. 1995, 14, 142-153.

67. Nies, D. Heavy metal-resistant bacteria as extremophiles: Molecular physiology and biotechnological use of Ralstonia sp. CH34. Extremophiles 2000, 4, 77-82. [CrossRef] [PubMed]

68. Intorne, A.C.; de Oliveira, M.V.V.; Pereira, L.D.M.; de Souza Filho, G.A. Essential role of the $c z c$ determinant for cadmium, cobalt and zinc resistance in Gluconacetobacter diazotrophicus PAl 5. Int. Microbiol. 2012, 15, 69-78. [PubMed]

69. Chandra, B.R.; Yogavel, M.; Sharma, A. Structural analysis of ABC-family periplasmic zinc binding protein provides new insights into mechanism of ligand uptake and release. J. Mol. Biol. 2007, 367, 970-982. [CrossRef] [PubMed]

70. Madhaiyan, M.; Poonguzhali, S.; Sa, T. TE tolerating methylotrophic bacteria reduces nickel and cadmium toxicity and promotes plant growth of tomato (Lycopersicon esculentum L.). Chemosphere 2007, 69, 220-228. [CrossRef]

71. Mesa, J.; Mateos-Naranjo, E.; Caviedes, M.A.; Redondo-Gómez, S.; Pajuelo, E.; Rodríguez-Llorente, I.D. Endophytic cultivable bacteria of the TE bioaccumulator Spartina maritima improve plant growth but not TE uptake in polluted marshes soils. Front. Microbiol. 2015, 6, 1450. [CrossRef]

72. DalCorso, G.; Manara, A.; Furini, A. An overview of heavy TE challenge in plants: From roots to shoots. Metallomics 2013, 5, 1117-1132. [CrossRef]

73. Nazar, R.; Iqbal, N.; Masood, A.; Khan, M.I.R.; Syeed, S.; Khan, N.A. Cadmium toxicity in plants and role of mineral nutrients in its alleviation. Am. J. Plant Sci. 2012, 3, 1476. [CrossRef]

74. Cakmak, I.; Yazici, A.M. Magnesium: A forgotten element in crop production. Better Crops 2010, 94, $23-25$.

75. Cakmak, I.; Kirkby, E.A. Role of magnesium in carbon partitioning and alleviating photooxidative damage. Physiol. Plant 2008, 133, 692-704. [CrossRef]

76. Rengel, Z.; Bose, J.; Chen, Q.; Tripathi, B.N. Magnesium alleviates plant toxicity of aluminium and heavy metals. Crop. Pasture Sci. 2016, 66, 1298-1307. [CrossRef] 